\title{
A Christian Cancellation of the Secularist Truce? Waning Christian Religiosity and Waxing Religious Deprivatization in the West
}

\author{
PETER ACHTERBERG \\ Department of Sociology \\ Erasmus University
}

STEF AUPERS

Department of Sociology

Erasmus University

PETER MASCINI

Department of Sociology

Erasmus University

\author{
DICK HOUTMAN \\ Department of Sociology \\ Erasmus University
}

WILlEM DE KOSTER

Department of Sociology

Erasmus University

JEROEN VAN DER WAAL

Department of Sociology

Erasmus University

\begin{abstract}
Analysis of International Social Survey Program (ISSP) data collected in 18 Western countries in 1998 demonstrates that Christian desires for a public role of religion are strongest in countries where Christian religiosity is numerically most marginal. Moreover, Dutch data covering the period 1970-1996 confirm that the decline of the number of Christians in the Netherlands has been coincided by a strengthening of the call for public religion among the remaining faithful and by increased polarization about this with the nonreligious. Religious decline and religious privatization, two of the most crucial dimensions of secularization (Casanova 1994), hence develop dialectically: as the number of Christians declines, the remaining faithful seem increasingly unwilling to accept the "secularist truce"- the secularist contract that guarantees religious freedom yet bans religion from the public sphere by relegating it to the private realm.
\end{abstract}

During the last two decades secularization theory has lost much of its former aura. Once virtually uncontested and generally regarded empirically sound, a flow of critique has surged since the 1980s. Even its most important adherents of the past, such as Peter Berger (1967), have turned their positions: "The assumption that we live in a secularized world is false. The world today... is as furiously religious as it ever was, and in some places more so than ever. This means that a whole body of literature by historians and social scientists ... is essentially mistaken" (Berger 1999:2). Others argue that the theory of secularization has been exposed as ideology in disguise. Instead of a sound scientific theory, they regard it a mere dream that is intimately tied to the rationalist discourse of modernity (Hadden 1987:588; see also Stark and Bainbridge 1985; Stark and Finke 2000).

Many consider the secularization thesis as too broad and unspecific. Hadden, for instance, qualifies it as a "hotchpotch of loosely employed ideas rather than a systematic theory" (1987:587) —an observation that is neither new, nor confined to the theory's critics. About 40 years ago Shiner (1967) already pointed out that the concept of secularization contains at least six distinct dimensions, and a quarter of a century ago Dobbelaere (1981) emphasized that secularization takes radically different shapes at the micro-, meso- and macrolevels (see also Tschannen 1991). Steve Bruce (2002:39), one of the theory's principal proponents today, could not agree more and declares that "there is no secularization theory." A virtual consensus thus exists that "secularization theory" is a multiheaded dragon, an essentially incoherent bundle of loosely related subtheses with at best a Wittgensteinian "family resemblance." This lack of theoretical 
clarity spawns a confusing and hardly productive debate in which religious fundamentalism, for instance, can either be construed as contradicting secularization theory (e.g., Juergensmeyer 1993) or as confirming it, because "modern manifestations of fundamentalism ... presuppose that some kind of secularization is in progress-no fundamentalism without (prior) secularization" (Lechner 1991:1114).

In spite of this fuzziness, secularization theory has an uncontested core. Both adherents like Wilson (1976, 1982) and critics like Luckmann (1967, 2003) accept "the thesis of the differentiation of the religious and secular spheres" as "the still defensible core of the theory of secularization" (Casanova 1994:19). Virtually all sociologists of religion hence agree that religion was once a sort of "sacred canopy" that covered all domains of society (Berger 1967)—medieval art was still basically religious art, science and religion could not yet clearly be distinguished during the Renaissance, and today's separation of state and church in Western countries only came into existence after a long and painful historical struggle (e.g., Bell 1976; Wilson 1982).

Two subtheses in particular dominate the contemporary debate: "the decline-of-religion thesis" and the "privatization thesis" (Casanova 1994:19-20). The debate about the decline-ofreligion thesis is about whether, where, and why we are witnessing a decline of institutionalized, mainline church religion on the one hand (e.g., Houtman and Mascini 2002; Norris and Inglehart 2004) and religious innovation, revitalization, and cult formation, typically occurring outside the mainline churches, on the other (e.g., Heelas et al. 2005; Houtman and Aupers 2007; Houtman and Mascini 2002; Luckmann 1967; Stark and Bainbridge 1985; Yinger 1957).

The debate about the privatization thesis is about whether, where, and why we are witnessing either a confinement of religion to the domain of private life or an increasing tendency to push religion as a moral resource for the public domain. Luckmann's (1967) classical argument is that religion becomes increasingly privatized and hence socially and publicly insignificant and "invisible." Yet, various observers have rightly pointed out that religion has become more publicly significant in various countries since the 1980s (e.g., Casanova 1994; Conway 1996; Haynes 1998; Juergensmeyer 1993). Meanwhile, the privatization thesis has even been critiqued for misconstruing contemporary spirituality as radically privatized (Aupers and Houtman 2006; Besecke 2005; Grant, O’Neil, and Stephens 2004).

Creatively linking the study of individual religiosity to the study of the (de)privatization of religion, Chaves (1994:751) has critiqued the one-sided focus on the institutional level of society as a whole in studies of deprivatization - a focus informed by secularization theory's uncontested tenet that even apart from what may have happened to individual religiosity, "it is the system that has become secularized" (Wilson 1985:19).

More specifically, proceeding in a classical Weberian mode of reasoning, Chaves argues that this focus wrongly neglects the theoretically vital question of whether and how religion drives individual believers' social actions beyond the strictly private domain. He hence argues for the need to study secularization as the decline of religion's social significance for individual believers ("declining religious authority"). We follow Chaves's plea in this article by studying whether or not the decline of Christian religiosity in contemporary Western countries has been accompanied by a waning or rather a waxing of desires among Christians for an active role of religion in public life. If religious decline fuels rather than diminishes desires for a public role of religion among Christians, this would mean-in Casanova's terms used above - that religious decline produces desires for deprivatization. Such a finding would surely provide striking support for the case of abandoning all-too-general notions of secularization, made by authors such as Martin (1965), Shiner (1967), and Hadden (1987).

\section{Dialectics of Secularization?}

Somewhat surprising against the background of the almost universal acknowledgment that secularization is a multidimensional phenomenon, the possibility that its dimensions may develop 
in different directions has received only scant attention in the literature. The typical (albeit usually tacit) assumption is that declining levels of Christian religiosity tend to coincide with a decline in its social significance for the faithful (e.g., Halman, Petterson, and Verweij 1999). In his aforementioned plea for conceiving of secularization as a decline in religion's social significance for individual believers, Chaves (1994) does not seriously consider the alternative possibility of an increase in social significance either (see also Lechner 1991). In his historical critique of the debate on secularization, Gorski (2000:162) on the other hand stresses the importance of having an eye for the possibility that different dimensions of secularization may not necessarily develop in a similar fashion.

Acknowledging secularization's multidimensionality, Bruce (2002:39) also takes care to point out that "the secularization paradigm is not the sociological equivalent of synchronized swimming. It does not require or expect that all indices of religious vitality will decline at the same speed or evenly." As a consequence, he argues, secularization theory—or, more correct and preferred by Bruce, "the secularization paradigm"-is not threatened by minor or exceptional counterindications:

\begin{abstract}
We should never forget that [general social changes] are abstractions created by colour-washing the jagged edges of events in the real world. .. The jagged bits are a problem only if it can be plausibly argued that a different abstraction can be better drawn from the same material. If there are too many exceptions, then we should consider painting "growth" or even just "random fluctuations". But some small reversals need not trouble the paradigm. (2002:40)
\end{abstract}

This position can of course easily be translated into a testable proposition: if an all-out process of secularization is taking place, then we will surely find a number of outliers and exceptions, but the general pattern will be a decline of individual religiosity coinciding with a declining role of religion in driving preferences about the role of religion in public life.

Yet, a recent study conducted in the Netherlands-a country in which personal religiosity has dropped to much lower levels than in virtually all other countries in the world (Norris and Inglehart 2004) — suggests that social significance at the level of individual believers may have increased rather than decreased. Dekker (2007) finds evidence that the number of Christians who say that their belief is "significant" or "very significant" for them has increased by almost 30 percent (from 33 percent in 1979 to 42 percent in 2006):

\footnotetext{
The development already visible 10 years ago has continued during the last decade: faith plays a role in the lives of fewer and fewer people, yet becomes increasingly significant for those who do believe. Especially the number of believers who say that their faith is very significant in their lives has increased relatively very strongly. (2007:56; our translation from Dutch, emphasis in original)
}

This is a remarkable finding that goes way beyond the possibility that the various dimensions of secularization proceed at different paces, yet eventually all change in the same direction. The key question, as Bruce rightly emphasizes, is whether this finding is merely a "jagged bit" or exemplifies a more general pattern. If the latter is the case in the Netherlands and other Western countries, this would mean nothing less than that secularization in one respect-declining numbers of religious individuals - would be accompanied by desecularization in another-increasing aspirations for religion in the public domain among the remaining Christians. Three scenarios predict such a development.

First, it is of course conceivable that the spread of secularism affects less religious believers first and disproportionally, stimulating them to abandon their religious creeds, so that increasingly a hard core of passionate believers remains. If such a process occurs, religious decline produces a sort of "purification" of the religious population with the remaining believers increasingly affirming the necessity of a public role for religion. 
Second, as Western societies grow more heterogeneous, churches may feel increasingly forced to mobilize their congregations. As Luckmann (1967) already pointed out, structural differentiation after all erodes the monopoly of Christianity, yielding a market for ultimate significance in which various religious traditions "battle" for believers. The emergence of such a religious marketplace may go hand in hand with religious innovation (cf. Stark and Bainbridge 1985), may increase church attendance (Phillips 2004), and may cause the religious to fiercely reassert the public importance of their creed. Religious decline may hence also go together with heightened desires for a public role of religion because it is accompanied by increased religious heterogeneity.

Third, although Bruce aims to defend secularization theory against current charges and maintains that "religion diminishes in social significance, becomes increasingly privatized, and loses personal salience" (2002:30), he nonetheless points out that religion may be made more salient by the process of secularization itself. To be more precise, Christian identities may not only be reaffirmed through increases in religious heterogeneity, but also through the spread of secularism: "culture, identity and sense of worth are challenged by a source promoting either an alien religion or rampant secularism and that source is negatively valued" (2002:31).

\section{Hypotheses}

The three scenarios outlined above are clearly not identical. The first (purification of Christian religion), can occur in the absence of other religious traditions, while this is impossible in case of the second (increased competition by other religions). In the third scenario, increasing secularism may have similar consequences as the presence of competing religions. Just like in the first scenario, the presence of the latter is hence not assumed in the third one either. We will briefly return to these three scenarios in our conclusion.

We focus our analysis on what the three scenarios have in common and hence study the tenability of their shared assumption that religious decline goes together with increasing desires for deprivatization of religion among the remaining Christians. We study, in other words, whether Christian religiosity is most forcefully associated with desires for a public role of religion in precisely those contexts in which Christian believers are least numerous. We do so by comparing 18 contemporary Western countries, in some of which Christian religiosity is much more widespread than in others, and by studying changes across time in the Netherlands.

Besides obvious reasons of data availability (we need comparative data that cover a substantial period), there are two more substantial reasons to follow the process across time in the Netherlands only. This is, after all, not only the country in which religion has declined much more than anywhere else, but also the country for which at least some evidence for the assumed dialectics of secularization exists (Dekker 2007). Needless to say, the cross-national analysis of other Western countries is intended as a first rough test of whether the Netherlands constitutes an anomaly or may rather exemplify a more general pattern.

We test four hypotheses, the first two pertaining to differences between the 18 Western countries in 1998 and the last two to changes in the Netherlands during the period 1970-1996. As to the differences between countries, the three scenarios outlined above suggest that Christian aspirations for a public role of religion are strongest in countries where the number of Christians is lowest (hypothesis 1). Moreover, the gap in opinions between Christians and the nonreligious is expected to be wider in countries with fewer adherents of Christianity (hypothesis 2). As to changes in the Netherlands, we expect that the decrease in the number of Christians has led to increasing support for a public role of religion among them (hypothesis 3). We furthermore expect that the gap in the relevant opinions between Christians and the nonreligious has become wider as the number of Christians in the Netherlands has decreased (hypothesis 4). 
Table 1: Factor and reliability analysis for the scale for aspirations for religion in the public domain

Item

Factor

Loading

Do you think that churches and religious organizations in this country have too .77

much power or too little power?

Would your country be a better country if religion had less influence?

How much do you agree or disagree that religious leaders should not try to influence government decisions?

Religious leaders should not try to influence how people vote in elections

Cronbach's $\alpha$

N

Source: International Social Survey Program (1998).

\section{Data And Measures}

\section{Data}

For the comparison between Western countries we use the International Social Survey Program Religious II 1998 data set. In all countries included in the analysis, Christianity was the dominant religion during the second half of the previous century. These countries are: Australia (AUS), Austria (A), Canada (CND), Denmark (D), France (F), Great Britain (GB), Ireland (IRL), Italy (I), the Netherlands (NL), New Zealand (NZ), Northern Ireland (NIRL), Norway (N), Portugal (P), Spain (E), Sweden (S), the United States (US), Switzerland (CH), and West Germany (D-W).

The most relevant data files for the analysis on the Netherlands are the Cultural Changes (Culturele Veranderingen) surveys ranging from 1970 to 1996. For the technical reports of the International Social Survey Program and the Cultural Changes data sets, the reader is referred to www.iisp.org and www.dans.knaw.nl $\backslash$ nl $\backslash$ data $\backslash$, respectively.

\section{Measures}

Christian religiosity is measured simply as being a member of a Christian religious denomination or not. Respondents have been asked to indicate whether they were a member of a religious denomination and if so, which one. Those indicating not to be a member of a religious denomination, that is, the nonreligious, are coded as 1, while respondents indicating to be a member of one of the Christian denominations (especially Catholicism and various strains of Protestantism) ${ }^{1}$ are coded as 2 . As this article aims to study the relationship between the decline of the number of Christians and desires for a public role of Christian religion among the remaining Christians, non-Christian religions like Islam, Hinduism, and Buddhism have been coded as missing. ${ }^{2}$

\footnotetext{
${ }^{1}$ To be more precise: respondents indicating Roman Catholic, Greek Catholic, Druse, Baptist, Methodist, Lutheran, Presbyterian, Anglican, Congregationalist, Episcopal, Unitarian, Protestant (free church), Protestant (else), Orthodox, United Church CDN, Free Presbyterian, Brethren, Pentecostal, Mormon, Salvation Army, Seventh Day Adventists, Hussites, and other Christian religions as their denominations were coded as Christian.

${ }^{2}$ The number of non-Christian yet religious respondents in the Dutch data is very limited; they could literally be counted on two hands. For reasons of comparability, we have coded respondents with other than Christian denominations as missing in the ISSP data as well.
} 


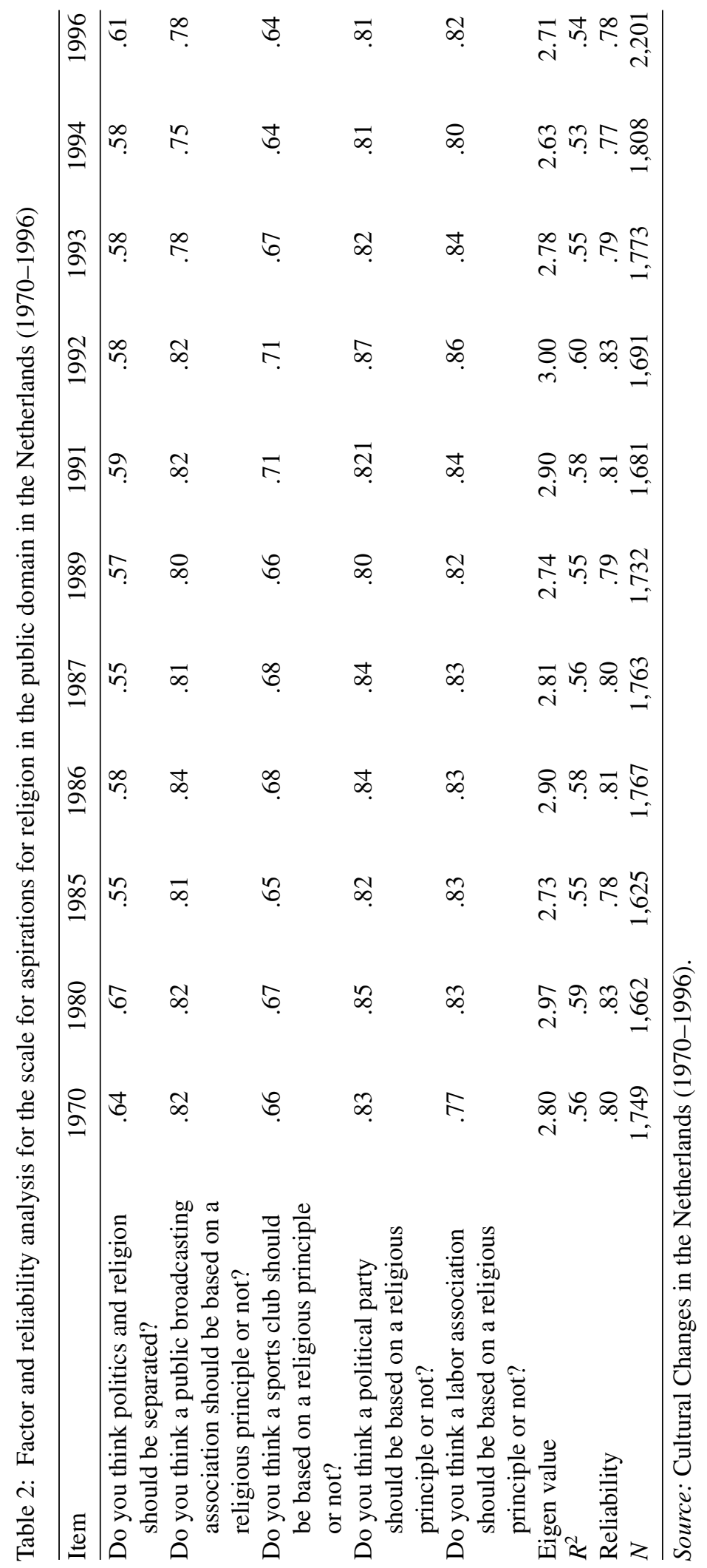


Aspirations for religion in the public domain is defined as support for influence of religion on public life, thus indicating a preference for deprivatization of religion. For the international comparison, it is measured using four Likert items that yield a reliable scale (see Table 1).

In the analysis of changes in the Netherlands, aspirations for religion in the public domain is measured with a reliable scale based on five items. The first item measures support for the separation of politics and religion, while the other four questions probe support for associations based on religious principles (public broadcasting associations, sports clubs, labor organizations, and political parties). The reliability of this scale ranges from .77 through .83 (see Table 2).

\section{Results}

In order to test our hypotheses, we have conducted our analyses in three steps. First, we study how the mean support for a public role of religion among Christians is associated with the proportion of Christians in the population. Second, we determine whether the relationship between individual Christian religiosity and aspirations for religion in the public domain is stronger in contexts where Christianity has least adherents. Finally, we study whether this means that strongest polarization between Christians and nonreligious in this exists in contexts in which Christians are least numerous. The three steps are first performed for the cross-sectional international comparison and then repeated to study longitudinal trends within the Netherlands.

From Figure 1 it can be concluded that a negative relationship exists between the proportion of Christians in a country and support of these Christians for a public role of religion. As expected, then, Christian aspirations for a public role of Christian religion are weaker in countries with more Christians. Put differently, in massively Christian countries such as Ireland, Portugal, and Italy, Christians attach not more, but less value to a public role of religion than in much less

Figure 1

The association between the mean aspirations for religion in the public domain of Christians and the proportion of Christians in Western countries, 1998, $N=18$ (Pearson's $r=-.72$ )

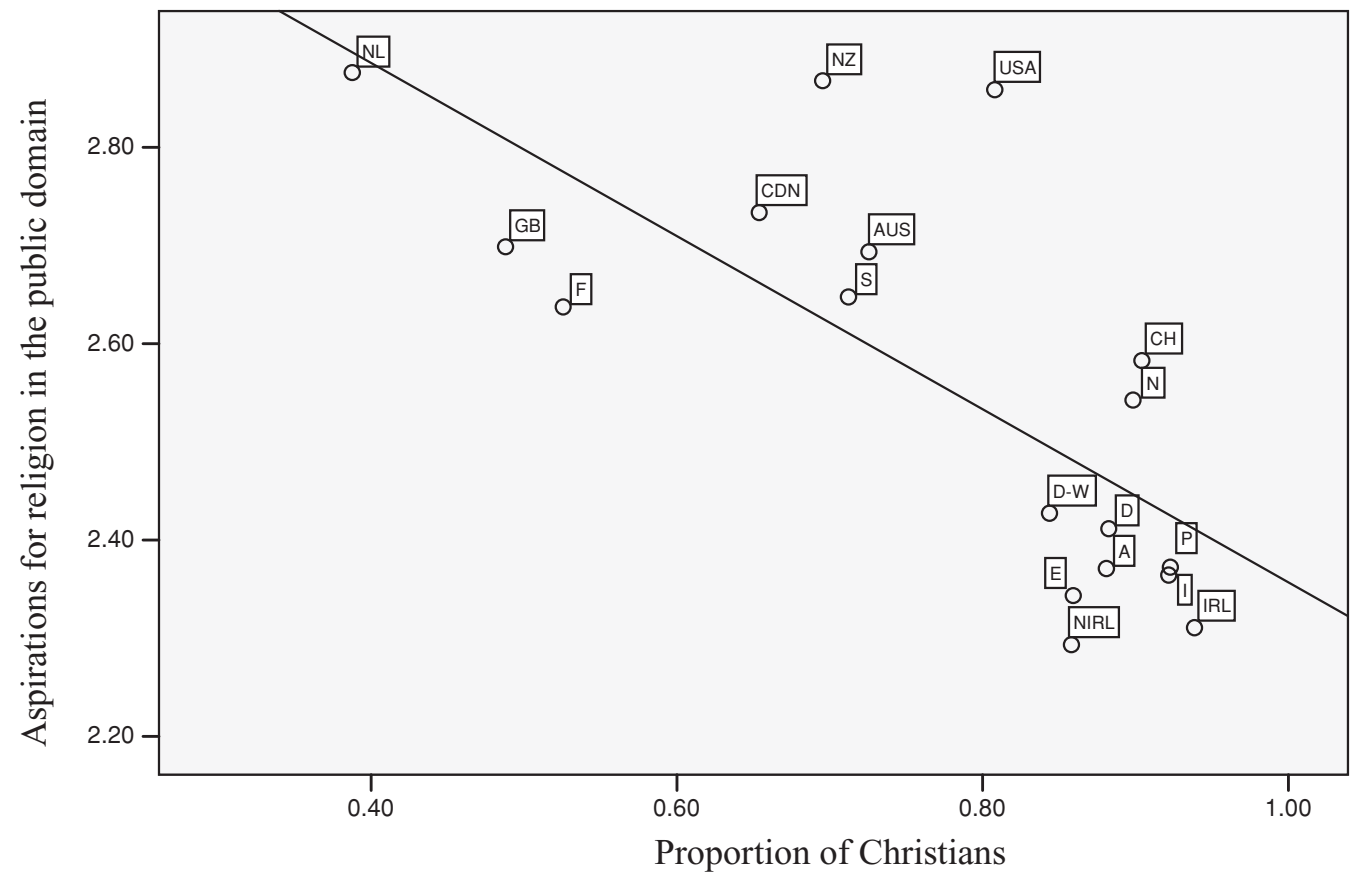


Figure 2

Association between the effect of individual Christian religiosity on aspirations for religion in the public domain and the proportion of Christians in Western countries, 1998, $N=18$

(Pearson's $r=-.70$ )

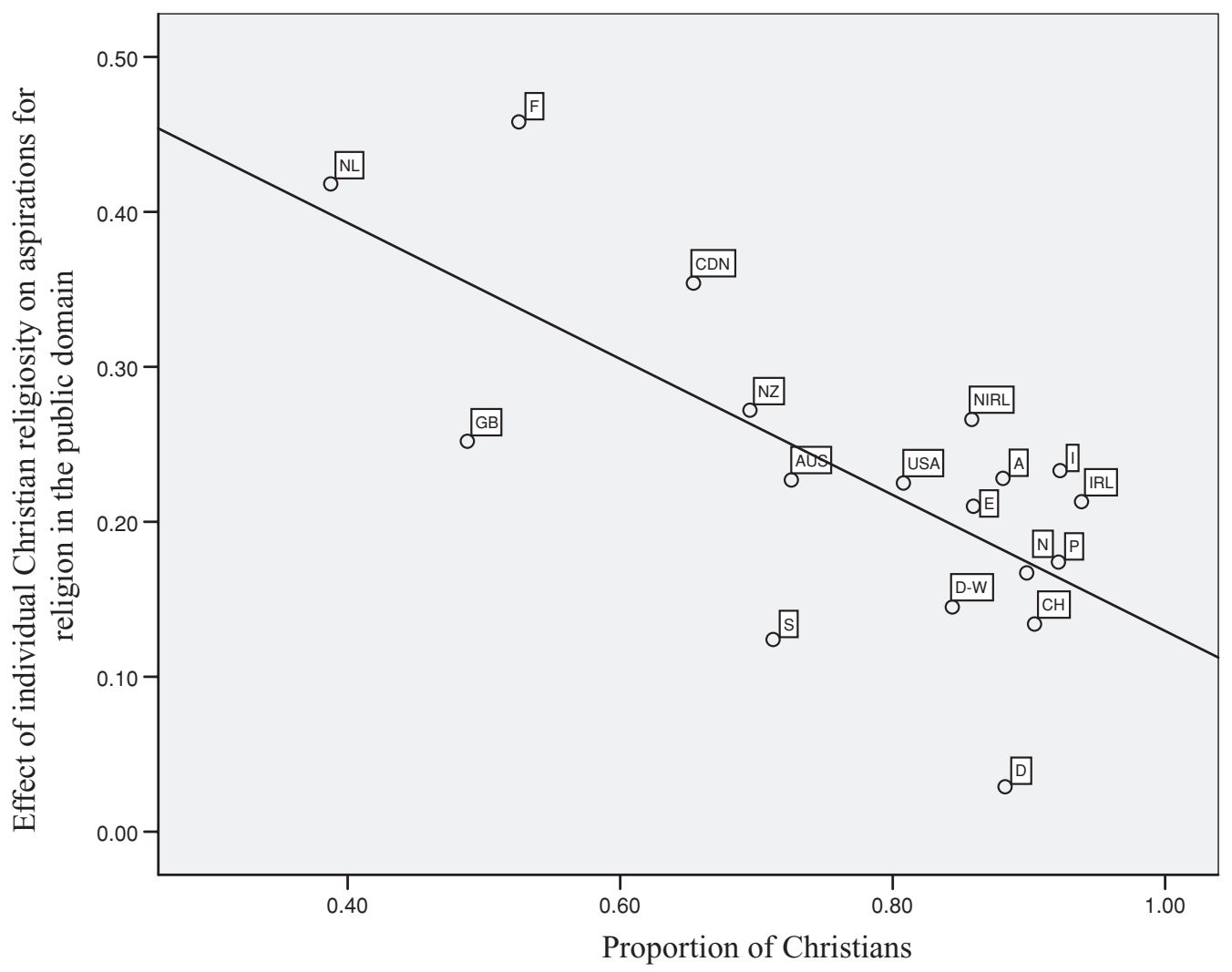

Christian countries such as the Netherlands and Great Britain. Given the strong and statistically significant differences between countries, the first hypothesis can be accepted.

Figure 2 depicts the association between the proportion of Christians per country and the degree to which aspirations for religion in the public domain are influenced by Christian religiosity, that is, membership of a Christian denomination. ${ }^{3}$ As expected, the relationship is negative. This means that opinion polarization between Christians and the nonreligious on the desired role of religion in the public sphere is strongest in countries where Christians are least numerous, such as France or the Netherlands.

In line with hypothesis 2, Figure 3 makes clear that differences in aspirations for religion in the public domain between Christians and non-Christians are indeed smallest in countries where the proportion of Christians is highest. In other words, the polarization between Christians and non-Christians about beliefs on the public role of religion is strongest in countries where Christians are least numerous. Hence, our second hypothesis is confirmed as well.

Our cross-sectional hypotheses are hence corroborated: in countries with smaller shares of Christians, the latter distinguish themselves most decidedly when it comes to desires for a public

\footnotetext{
${ }^{3}$ Technically speaking, Figure 2 shows a cross-level interaction, as does Figure 6. Although, strictly speaking, testing this type of interactions should be done with multilevel analysis, we have opted for an alternative analysis because of the small $N$ at the country level $(N=18)$ and the year level $(N=6$ and $N=11)$.
} 
Figure 3

The association between the difference in mean aspirations for religion in the public domain between Christians and non-Christians and the proportion of Christians in Western countries, $1998, N=18$ (Pearson's $r=-.26$ )

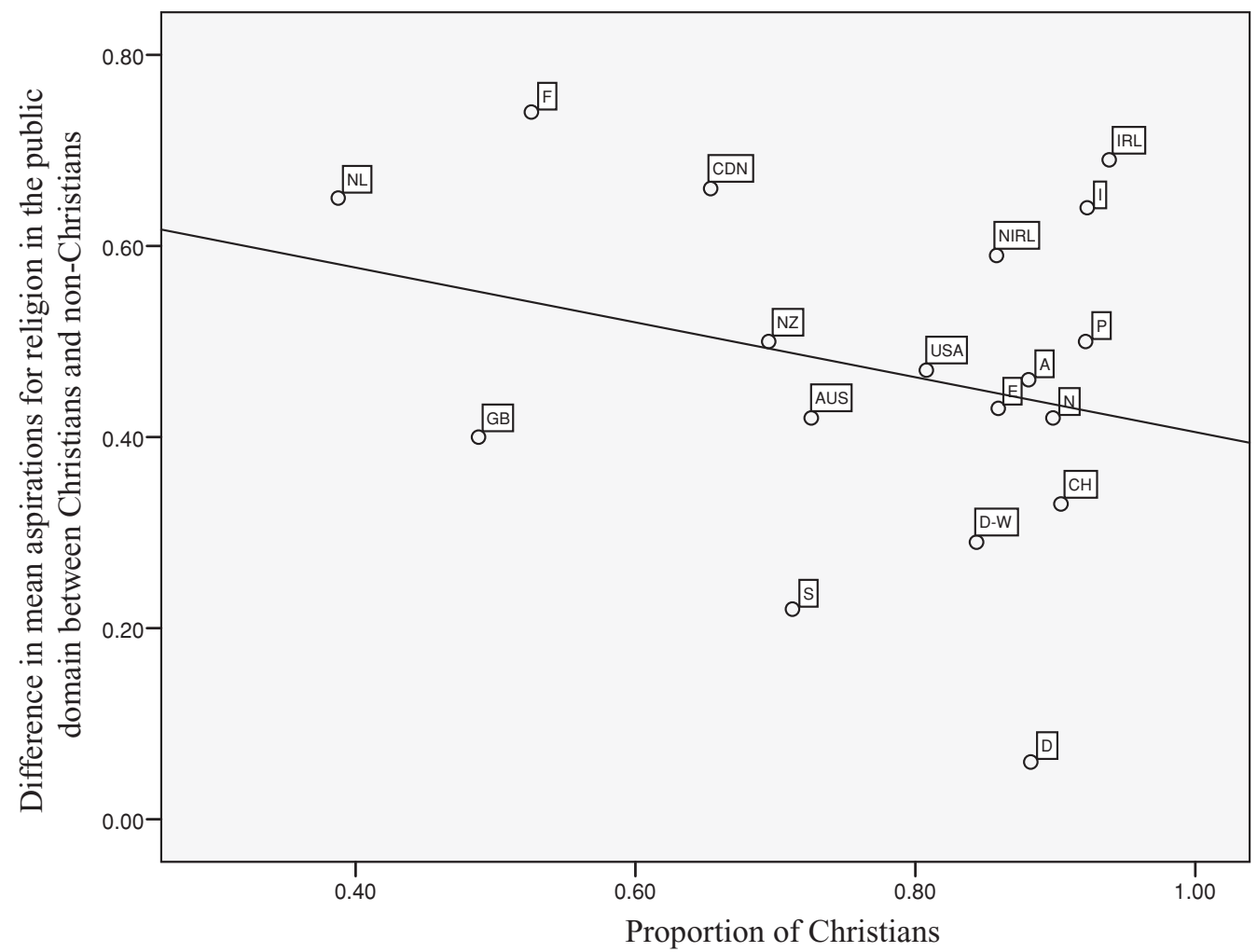

role of religion. This brings us to our longitudinal inquiry for the Netherlands. Because in the Netherlands Christian religiosity has declined more than anywhere else, as Figures 1-3 have already shown (see also Norris and Inglehart 2004), this country is a strategic case for such an assessment. As Figure 4 demonstrates as well, Christian religiosity has decreased dramatically in the Netherlands.

As expected, the decline in the proportion of Christians in the Netherlands has been accompanied by stronger Christian desires for a public role of religion (see Figure 5). Just like we have seen in the international comparison, then, support for a public role for religion has increased among Christians while the number of Christians itself has declined-confirming hypothesis 3 .

Figure 6 indicates that the impact of individual religiosity on aspirations for religion in the public domain varies across years with the proportion of Christians in a given year. Consistent with our expectations, the relationship is negative: the association between individual Christian religiosity and opinions about the public role of religion has become stronger as the number of Christians has declined. Finally, Figure 7 demonstrates that the differences between Christians and non-Christians were quite small when there were still many Christians in the Netherlands, while the gap has widened as their number has declined. Our fourth and last hypothesis is hence also accepted.

It is clear from our findings that the decline in the number of Christians in the West does not imply that the remaining faithful have increasingly come to accept the relegation of their creed to the private realm. The trends found for the Netherlands since 1970 and the cross-national patterns 
Figure 4

The decline of Christian religiosity in the Netherlands, 1970-1996, $N=14$ (Pearson's $r=-.83$ )

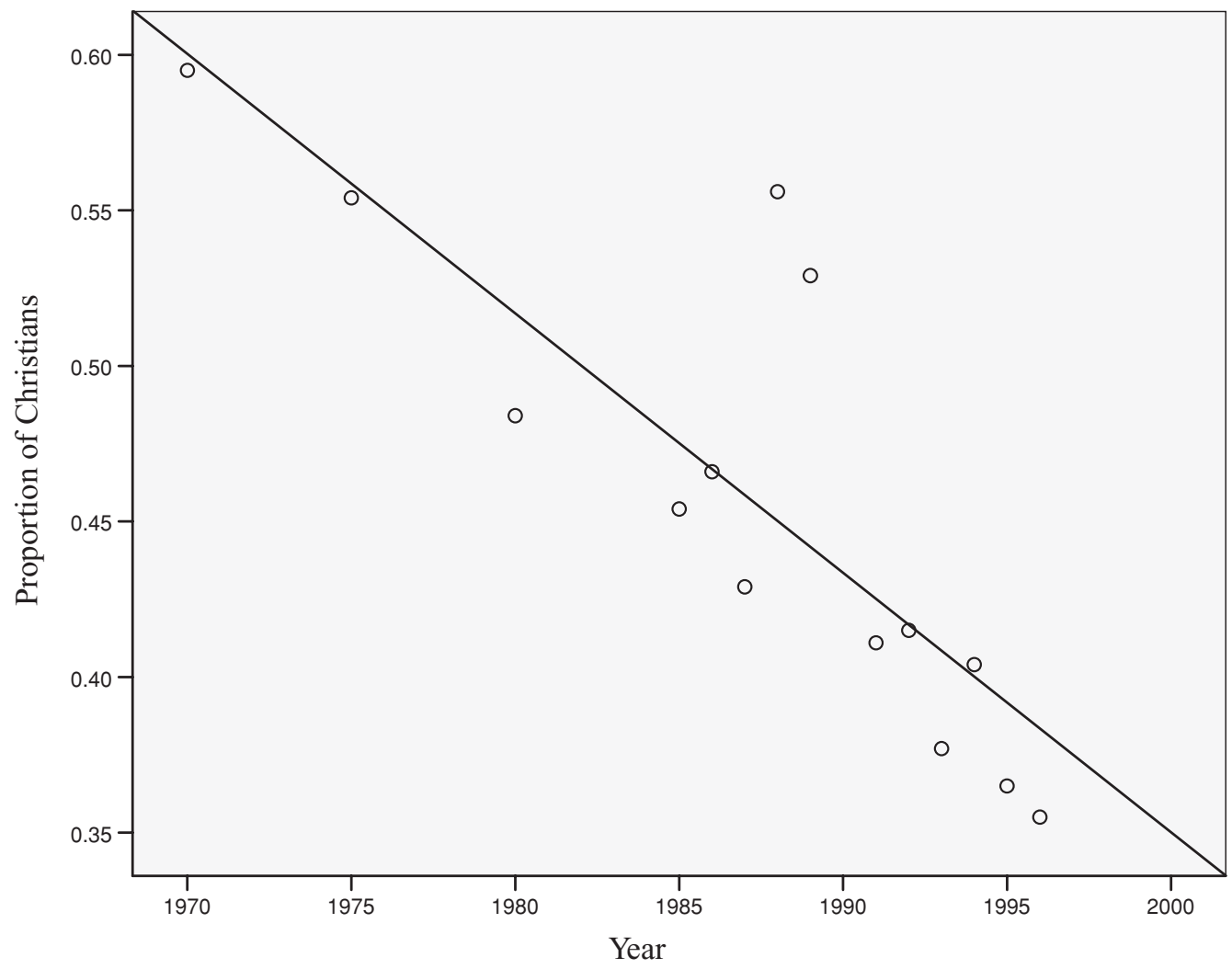

found for 18 Western countries rather point in the direction of a stronger assertion of the public relevance of religion among those who have remained faithful.

\section{Conclusion And Discussion}

Since the 1980s, the once virtually uncontested theory of secularization has been under debate in the social sciences. The debate is mainly characterized by an exchange of arguments pro and contra with "the effect of inducing a certain theoretical sterility and repetitiveness within the discipline" (Chaves 1994:749). This has led to an intellectual cul-de-sac with scholars retreating into their theoretical trenches, exchanging arguments intended to either critique or defend secularization theory. In this article, we have demonstrated that this ongoing debate about "whether or not" secularization takes place is indeed problematic.

While Christian religion has for many lost its former appeal in most Western countries in recent decades, those who have remained loyal to it seem more rather than less eager than before to assert the public relevance of their creed. In Casanova's (1994) terms: religious decline seems to go along with increasing desires for deprivatization, indicating secularization and desecularization, respectively, and as such ruling out the possibility of "all-out" claims about "whether or not" secularization takes place. Though Christians in the West have experienced substantial declines in terms of sheer numbers, our findings hence suggest that they have become less rather than more likely to accept the "secularist truce"- the secularist contract that guarantees religious freedom, 
Figure 5

The association between the mean aspirations for religion in the public domain of Christians and the proportion of Christians in the Netherlands, 1970-1996, $N=11$ (Pearson's $r=-.71$ )

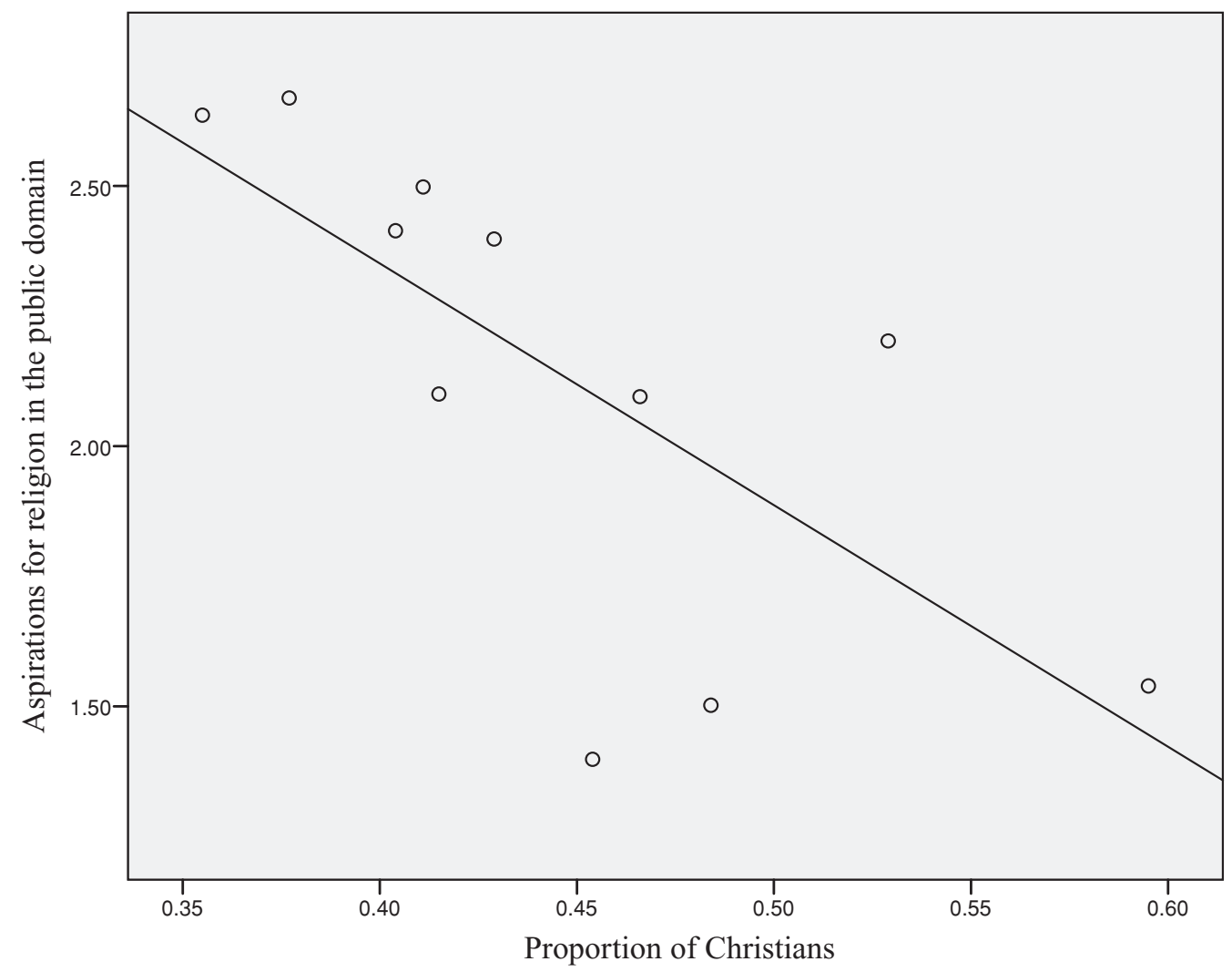

yet bans religion from the public sphere by relegating it to the private realm (see also Taylor 2007).

On a theoretical level, our findings on these dialectics of secularization and desecularization resonate in particular with the arguments by Stark and Bainbridge (1985), Luckmann (1967), and Bell (1977). These perspectives are, however, not unproblematic because they formulate similar ideas about dialectics of secularization in vague, neo-Freudian terms such as the "return of the repressed" (Giddens 1991:207) without being specific about exactly how, why, and under which cultural circumstances religion fights its way back into late-modern society or aims to strengthen its position. Stark and Bainbridge, for instance, simply consider secularization a "self-limiting process" and since they assume that "the amount of religion remains relatively constant," religious decline will —in their view—always be accompanied by religious innovation and experimentation (Stark and Bainbridge 1985:2-3). In a similar vein, Bell has argued "that very destruction [of 'aura'] — and the realization of that fact—is itself a starting point of a new response" (1977:444). Underneath these all-too-sweeping accounts, the nonsociological and even metaphysical assumption of religion as a basic anthropological condition and a universal need of man is looming large. Man is taken to be a homo religiosus (Luckmann 1967) and it is hence assumed that religion will prevail simply because people in all eras and cultures will always have to struggle with death, illness, and problems of meaning. Indicative of such a metaphysical line of reasoning is the following quote from Daniel Bell: 
Figure 6

Association between the effect of individual Christian religiosity on aspirations for religion in the public domain and the proportion of Christians in the Netherlands, 1970-1996, $N=11$

(Pearson's $r=-.38$ )

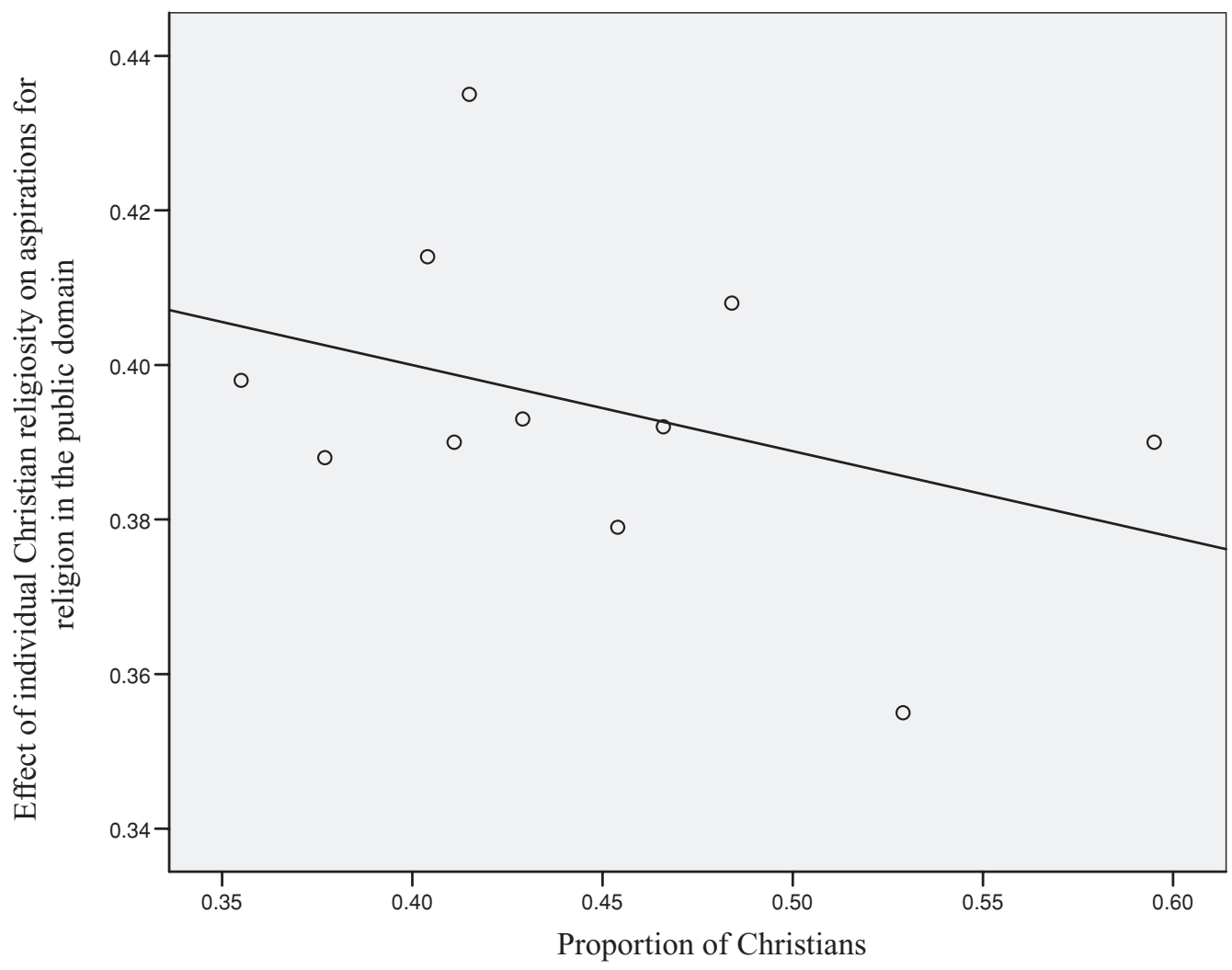

Will there be a return of the sacred, the rise of new religious modes? Of that I have no doubt.... The ground of religion is existential: the awareness of men of their finiteness and the inexorable limits to their powers, and the consequent effort to find a coherent answer to reconcile them to that human condition. $(1977: 444,447)$

We distance ourselves from these speculations on the status of religion as a constant anthropological condition since assumptions like these can, by their very nature, not be verified nor falsified in an empirical sense. Nevertheless, our findings do resonate with the general approach of secularization as a "self-limiting process." In this respect, it is important that Bruce (2002:33) suggests that a temporary revival of religiosity does not necessarily entail a process of desecularization. Under particular conditions, he argues, religion may temporarily flower, simply indicating that secularization does not proceed in a straight, linear fashion. Our findings, however, demonstrate a solid, long-standing trend instead of just a "jagged bit": the increased assertion of religion's public role is systematically related to its numerical decline.

Our findings provide a basis for future research in three ways. First, our findings could inspire research addressing the question why these remarkable dialectical trends are occurring. Above, we have distinguished three mechanisms that might explain why the different dimensions of secularization develop in opposite directions. Which of these mechanisms underlies the dialectics of secularization is still an open question, as our article merely provides a description of this process. Future research aimed at fleshing out the roles of these mechanisms is hence called for. 


\section{Figure 7}

The association between the difference in mean aspirations for religion in the public domain between Christians and non-Christians and the proportion of Christians in the Netherlands, 1970-1996, $N=11$ (Pearson's $r=-.28$ )

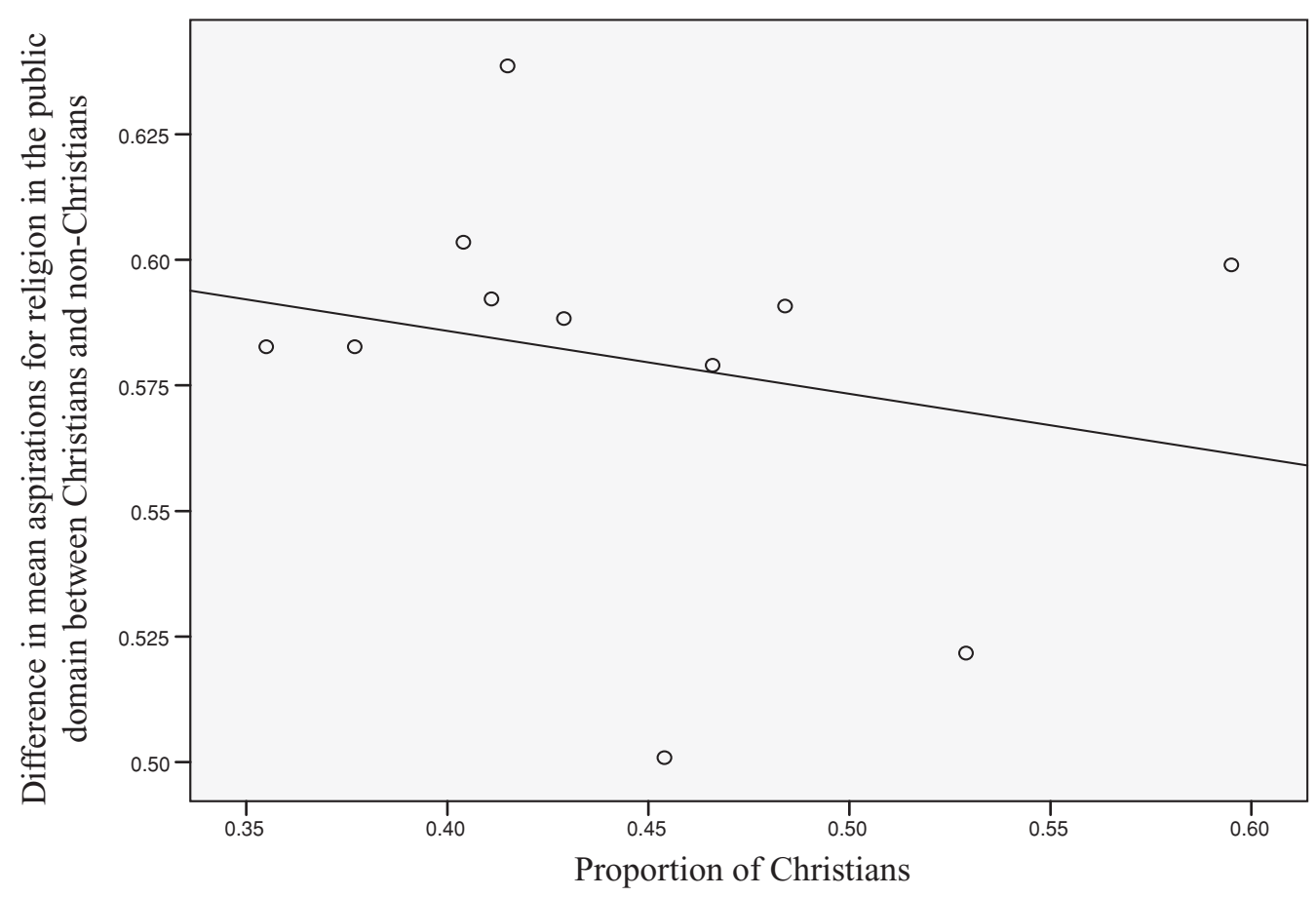

Second, our research has focused only on the public importance people attach to religion, and not so much on the role of religion in various other domains of life. For instance, we already know from other studies that individual religiosity matters more for moral and political values in contexts where the number of Christians is lowest (Houtman 2003; Scheepers, Te Grotenhuis, and DerSlik 2002). Yet, as Chaves (1994) rightly observes, religion's increased salience does not only reveal itself in its greater sway over personal values but over personal behavior, too. The circumstance that individual religiosity more strongly affects membership of and activity within voluntary associations in more secular contexts points in the latter direction (Ruiter 2008), but future research should also explore this issue by looking, for instance, at voting behavior, mating behavior, and school choice.

Third, the increased polarization between Christians and non-Christians found in this article sheds a new light onto the so-called Culture Wars debate. In this debate, fueled by the works of Hunter $(1991,1994)$, social scientists argue about the question whether or not there is increased polarization about religiously inspired moral and cultural issues such as abortion, homosexuality, and the like. This debate has given rise to empirical studies investigating the degree to which there is a growing disagreement between individuals over these types of issues. However, Hunter's polarization thesis has hardly been corroborated empirically (compare Dimaggio, Evans, and Bryson 1996; Evans and Bryson 2001; Mouw and Sobel 2001). Yet, the idea of cultural polarization lingers on in the minds of sociologists and political scientists. While the aforementioned studies have focused on differences between individuals, we have explored differences between categories of people (i.e., Christians and nonreligious) in this study to find an increase of polarization (see also Achterberg 2006:113-17; Hoffmann and Miller 1997). In order to further assess the empirical tenability of the culture wars argument, 
future research could hence explore polarization between groups and subcultures instead of individuals.

\section{REFERENCES}

Achterberg, Peter. 2006. Considering cultural conflict: Class politics and cultural politics in western societies. Maastricht, Netherlands: Shaker Publishers.

Aupers, Stef, and Dick Houtman. 2006. Beyond the spiritual supermarket: The social and public significance of new age spirituality. Journal of Contemporary Religion 21(2):201-22.

Bell, Daniel. 1976. The cultural contradictions of capitalism. New York: Basic Books.

- 1977. The return of the sacred? The argument on the future of religion. British Journal of Sociology 28(4):419-49.

Berger, Peter. 1967. The sacred canopy: Elements of a sociology of religion. New York: Doubleday.

- 1999. The desecularization of the world: A global overview. In The desecularization of the world: Resurgent religion and world politics, edited by Peter L. Berger, pp. 1-18. Grand Rapids, MI: William B. Eerdmans.

Besecke, Kelly. 2005. Seeing invisible religion: Religion as a societal conversation about transcendent meaning. Sociological Theory 23(2):179-96.

Bruce, Steve. 2002. God is dead: Secularization in the West. Oxford: Blackwell.

Casanova, José. 1994. Public religions in the modern world. Chicago, IL: University of Chicago Press.

Chaves, Mark. 1994. Secularization as declining religious authority. Social Forces 72(3): 749-74.

Conway, Martin. 1996. Introduction. In Political Catholicism in Europe, 1918-1965, edited by Tom Buchanan and Martin Conway, pp. 1-33, Oxford: Clarendon Press.

Dekker, Gerard. 2007. Het christelijk godsdienstig leven. In God in Nederland 1996-2006, edited by Ton Bernts, Gerard Dekker, and Joep de Hart, pp. 12-73. Kampen, Netherlands: Uitgeverij Ten Have.

DiMaggio, Paul, John Evans, and Bethany Bryson. 1996. Have Americans' social attitudes become more polarized? In Culture wars in American politics: Critical reviews of a popular myth, edited by Rhys Williams, pp. 63-100. New York: Aldine de Gruyter.

Dobbelaere, Karel. 1981. Secularization: A multi-dimensional concept. London: Sage.

Evans, John, and Bethany Bryson. 2001. Opinion polarization: Important contributions, necessary limitations. American Journal of Sociology 106(6):944-60.

Giddens, Anthony. 1991. Modernity and self-identity: Self and society in the late modern age. Cambridge: Polity.

Gorski, Philip S. 2000. Historicizing the secularization debate: Church, state, and society in late medieval and early modern Europe, ca. 1300 to 1700. American Sociological Review 65(1):138-67.

Grant, Don, Kathleen O'Neil, and Laura Stephens. 2004. Spirituality in the workplace: New empirical directions in the study of the sacred. Sociology of Religion 65(3):265-83.

Hadden, Jeffrey. 1987. Towards desacralizing secularization theory. Social Forces 65(3):587-610.

Halman, Loek, Thorleif Petterson, and Johan Verweij. 1999. The religious factor in contemporary society: The differential impact of religion on the private and public sphere in comparative perspective. International Journal of Comparative Sociology 40(1):141-59.

Haynes, Jeff. 1998. Religion in global politics. London and New York: Longman.

Heelas, Paul, Linda Woodhead, Benjamin Seel, Bronislaw Szerszynski, and Karin Tusting. 2005. The spiritual revolution: Why religion is giving way to spirituality. Oxford: Blackwell.

Hoffmann, John P., and Allan S. Miller. 1997. Social and political attitudes among religious groups: Convergence and divergence over time. Journal for Scientific Study of Religion 36(1):52-70.

Houtman, Dick. 2003. Class and politics in contemporary social science: "Marxism lite" and its blind spot for culture. New York: Aldine de Gruyter.

Houtman, Dick, and Stef Aupers. 2007. The spiritual turn and the decline of tradition: The spread of post-Christian spirituality in fourteen western countries (1981-2000). Journal for the Scientific Study of Religion 46(3):305-20.

Houtman, Dick, and Peter Mascini. 2002. Why do churches become empty, while new age grows? Secularization and religious change in the Netherlands. Journal for the Scientific Study of Religion 41(3):455-73.

Hunter, James D. 1991. Culture wars: The struggle to define America. New York: Basic Books.

- 1994. Before the shooting begins: Searching for democracy in America's culture war. New York: Free Press.

Juergensmeyer, Mark. 1993. The new cold war? Religious nationalism confronts the secular state. Berkeley and Los Angeles, CA: University of California Press.

Lechner, Frank J. 1991. The case against secularization: A rebuttal. Social Forces 69(4):1103-19.

Luckmann, Thomas. 1967. The invisible religion: The problem of religion in modern society. London: MacMillan. 2003. Transformations of religion and morality in modern Europe. Social Compass 50(3):275-85.

Martin, David. 1965. Towards eliminating the concept of secularization. In Penguin survey of the social sciences, edited by Julius Gould, pp. 169-82. Baltimore, MD: Penguin.

Mouw, Ted, and Michael. E. Sobel. 2001. Culture wars and opinion polarization: The case of abortion. American Journal of Sociology 106(4):913-43. 
Norris, Pippa, and Ronald Inglehart. 2004. Sacred and secular: Religion and politics worldwide. Cambridge: Cambridge University Press.

Phillips, Rick. 2004. Can rising rates of church participation be a consequence of secularization? Sociology of Religion 65(2):139-53.

Ruiter, Stijn. 2008. Association in context and association as context: Causes and consequences of voluntary association involvement. ICS-dissertation: Nijmegen, Netherlands.

Scheepers, Peer, Manfred Te Grotenhuis, and Frans V. DerSlik. 2002. Education, religiosity and moral attitudes: Explaining cross-national effect differences. Sociology of Religion 63(2):157-77.

Shiner, Larry. 1967. The concept of secularization in empirical research. Journal for the Scientific Study of Religion 6(2):202-20

Stark, Rodney, and William S. Bainbridge. 1985. The future of religion: Secularization, revival and cult formation. Berkeley, CA: University of California Press.

Stark, Rodney, and R. Finke. 2000. Acts of faith: Explaining the human side of religion. Berkeley, CA: University of California Press.

Taylor, Charles. 2007. A secular age. Cambridge, MA: Harvard University Press.

Tschannen, Oliver. 1991. The secularization paradigm: A systematization. Journal for the Scientific Study of Religion 30(4):395-415.

Wilson, Bryan. 1976. Aspects of secularization in the West. Japanese Journal of Religious Studies 3(4):259-76.

—. 1982. Religion in sociological perspective. Oxford: Oxford University Press.

1985. Secularization: The inherited model. In The sacred in a secular age, edited by Phillip E. Hammond, pp. 9-20. Berkeley, CA: University of California Press.

Yinger, J. Milton. 1957. Religion, society and the individual. New York: Macmillan. 